\title{
HLA-B44-Restricted Tyrosinase Peptide
}

National Cancer Institute

\section{Source}

National Cancer Institute. HLA-B44-Restricted Tyrosinase Peptide. NCI Thesaurus. Code C48634.

A synthetic peptide consisting of synthetic human leukocyte antigen (HLA)-B44-binding peptides derived from amino acid sequences of the melanoma-associated enzyme tyrosinase with potential antitumor activity. Vaccination with HLA-B44-restricted tyrosinase peptide may stimulate cytotoxic $T$ lymphocyte response against tyrosinaseexpressing tumor cells, resulting in decreased tumor growth and cell lysis. 